\title{
The Effects of Pulsed Electromagnetic Fields on Blood components, Antioxidant enzymes and Reactive Oxygen in Hyperlipidemic Rats
}

\author{
Hyun-Soo Bang*, In-Ho Jeong ${ }^{* *}$, Sang-Deok Lee ${ }^{* * *}$ \\ Dept. of Physical Therapy, Gimcheon University ${ }^{*}$ \\ Dept. of Dental Technology, Gimcheon University ${ }^{* *}$ \\ Dept. of Optometry, Gimcheon University ${ }^{* * * *}$

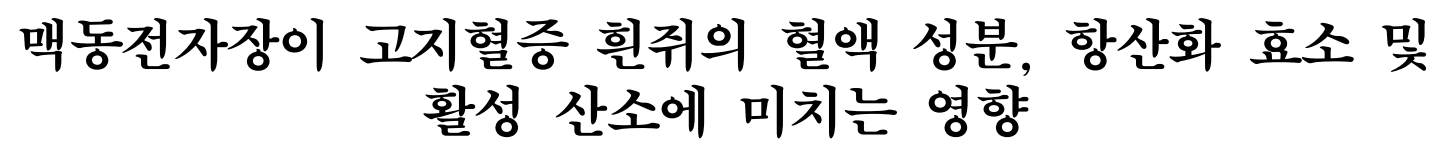 \\ 방현수 ${ }^{*}$, 정인호 ${ }^{* *}$, 이상덕 ${ }^{* *}$ \\ 김천대학교 물리치료학과*, 김천대학교 치기공학과 ${ }^{* *}$, 김천대학교 안경광학과 ${ }^{* *}$
}

\begin{abstract}
The present study was aimed to investigate the effects of the application of pulsed electromagnetic fields on the blood components associated hyperlipidemia, antioxidant enzymes and reactive oxygen. The subjects were divided into three groups: General Diet, High fat Diet, High fat diet and pulsed electromagnetic fields. Pulsed electromagnetic field was applied with pulsed electromagnetic energy therapy equipment. The Glucose, free fatty acids, triglycerides, cholesterol and insulin was used to measure hyperlipidemia-related blood components, and the GSH, GRD, XO and MDA was used to measure antioxidant enzymes and reactive oxygen. The applied pulsed electromagnetic field has improved the concentrations of blood components and increasing GSH and GRD, that were decreased due to a high-fat diet and by reducing the increased MDA and $\mathrm{XO}$ to a level of general diet group. Therefore, the applied pulsed electromagnetic field can be the effective treatment for changes in the blood composition of hyperlipidemic rats, enhancement of antioxidative activity and the inhibition of reactive oxygen.
\end{abstract}

Key Words : Pulsed electromagnetic field, Blood components, Antioxidant enzyme, Reactive oxygen, Hyperlipidemic

요 약 본 연구는 맥동전자장이 고지혈증 관련 혈액 성분, 항산화 효소와 활성 산소에 어떠한 영향을 미치는 지를 관찰하기 위하여 실시하였다. 실험군은 정상식이군, 고지방식이군과 고지방식이-맥동전자장 적용군의 3 군으로 나누었 다. 맥동 전자장은 맥동 전자장 에너지 치료기를 이용하였다. 혈액 성분의 검사 항목은 혈당, 유리지방산, 중성지방 및 콜레스테롤, 인슐린이고, 항산화 효소와 활성 산소의 검사는 글루타치온, 글루타치온 환원효소, 크산틴, 과산화지 질을 측정하였다. 그 결과 맥동전자장 적용은 혈액 구성성분과 $\mathrm{GSH}$ 와 $\mathrm{GRD}$ 를 고지장식이 수준에서 정상식이 수준 으로 상승시켰으며, XO와 MDA는 고지방식이 수준에서 정상 식이 수준으로 낮추어 주는 개선효과를 나타내었다. 그 러므로 맥동전자장의 적용은 고지혈증 흰쥐의 혈액성분의 변화, 항산화 효소의 증가, 활성 산화의 억제에 효과적인 치료 방법이라 할 수 있다.

주제어 : 맥동전자장, 혈액 성분, 항상화 효소, 활성 산소, 고지혈증

Received 9 April 2014, Revised 11 May 2014

Accepted 20 July 2014

Corresponding Author: Hyun-soo Bang(Gimcheon University)

Email:76044860@hanmail.net

ISSN: $1738-1916$
(C) The Society of Digital Policy \& Management. All rights reserved. This is an open-access article distributed under the terms of the Creative Commons Attribution Non-Commercial License (http://creativecommons.org/licenses/by-nc/3.0), which permits unrestricted non-commercial use, distribution, and reproduction in any medium, provided the original work is properly cited. 


\section{Introduction}

Modern eating habits such as increased intake of animal lipids and lack of exercise due to the development of a variety of electronic media have been pointed out as the factors to increase the concentration of cholesterol in the blood, accordingly the hyperlipidemia population. Hyperlipidemia in one of the risk factors that cause atherosclerosis; the increase of blood cholesterol increases the incidence of coronary artery disease, resulting in the increased mortality rate from heart disease such as congestive heart failure [1-3]. Accordingly, various studies have been made and several ways are presented for the prevention of hyperlipidemia, among which some studies have reported that the application of exercise reduced blood lipid and increases skeletal muscle metabolism ability and mitochondrial counts, inducing muscle metabolism promotion and improving a variety of metabolic diseases effectively [3-5]. However, high-intensity exercise generates reactive oxygen, thus affects antioxidant mechanism for cell greatly; these changes cause long-term stress on the human body. Low-intensity endurance exercise such as walking has positive effects on the antioxidant capacity of the tissue but, in the case of overweight patients or patients with weakened leg muscle strength, these exercises also acts on the human body as high-intensity exercise, so the action of reactive oxygen is also reported to be increased induced by the increase of oxygen consumption [4,5].

Chemical and biological effects appear if electrical stimulation such as pulsed electromagnetic field is applied to the body. It has been reported that various effects occur such as in vivo chemical modification of the electrolyte, increased blood circulation, increased metabolism, phagocytosis and increased cell membrane permeability, which effects increase the skeletal muscle activity and performance, resulting in various effects generating from low-intensity endurance exercise occurs in skeletal muscles [6-8]. In addition, it has been reported that these effects increase the activity of antioxidant enzymes in skeletal muscles or protein expression, resulting in the improvement of and contribution to the antioxidant defense system [8-10].

There have been lots of previous studies on the changes in blood components in patients with hyperlipidemia and changes in antioxidant enzymes and reactive oxygen depending on various methods of exercise, but studies are very limited on the effects of electrical stimulation such as pulsating electromagnetic fields. Therefore, the present study was aimed to investigate the effects of the application of pulsed electromagnetic fields on the blood components associated hyperlipidemia, antioxidant enzymes and reactive oxygen, and to provide basic data on the effects of pulsating electromagnetic field on the improvement of hyperlipidemia.

\section{Methods}

\subsection{Study subjects}

The animals used in this experiment are three week-old, white male Spraque-Dawley rats weighing $50 \mathrm{~g}$. For experiments, the subjects were divided into three groups: normal diet group consuming ordinary solid feed (General Diet; GD, $\mathrm{n}=10$ ); group consuming high fat diet which accounts for 51 percent of total calories (High fat Diet; $\mathrm{HD}, \mathrm{n}=10$ ); and the group consuming high fat diet and applied with pulsed electromagnetic field (High fat diet + pulsed electromagnetic fields; HDP, $\mathrm{n}=10$ ). Each test group was fed with solid formulation feed for adaptation for one week before being fed with high fat feed for 8 weeks. The standard kennel was kept at a temperature of $25 \pm 2{ }^{\circ} \mathrm{C}$ and humidity of $65 \pm 5 \%$ and was adjusted with constant illumination and photoperiod and dark period cycle at 12-hour intervals, in order to meet the life cycle of the rats. 


\subsection{Application of pulsed electromagnetic field}

Pulsed electromagnetic field was applied with pulsed electromagnetic energy therapy equipment, Diapulse (Diapulse Corp., America). The application of pulsed electromagnetic field was done using a $20 \mathrm{~cm}$ diameter air space plate in a distance of $5 \mathrm{~cm}$, at the frequency $27.12 \mathrm{MHz}$, pulsation frequency of 300 times per second, pulsation width $65 \mu$ s and duty cycle 1.95\%. Rats were put in a plastic case during the application to minimize the movement, for 20 minutes a time, 5 times a day, and a total of 6 weeks.

\subsection{Measurement and analysis of blood components, antioxidant enzymes and active oxygen}

Following the 6 week application of pulsating electromagnetic field, the test rats were anesthetized with $\mathrm{CO} 2$ gas and under went the ventral midline laparotomy, and blood samples were taken from the abdominal aorta and immediately centrifuged at $3,000 \mathrm{rpm}$ at $4^{\circ} \mathrm{C}$ for 20 minutes before removing the plasma, followed by being store at $-80^{\circ} \mathrm{C}$ for before analysis.

Glucose, free fatty acids, triglycerides and cholesterol were measured with a kit (Sigma Chemical Co, MO, USA) using enzymatic analysis; insulin concentrations were measured with Enzyme immuno-assay ELISA analysis kit (Mercodia AB, Uppsala, Sweden).

The content of lipid peroxide was displayed by adding 1/12N H2SO4 and 10\% phosphotungstic acid in the serum, pre-incubating the mixture at $20^{\circ} \mathrm{C}$ for 5 minutes, then centrifuging it and taking only serum proteins, the deposits, and displaying the content in malondialdehyde, The measurement of xanthine (XO) activity was done by adding $0.4 \mathrm{~m} \ell$ of the enzyme solution to $3.0 \mathrm{~m} \ell$ of $0.1 \mathrm{M}$ potassium phosphate buffer (pH 7.5), and adding $0.1 \mathrm{~m} \ell$ of $60 \mu \mathrm{M}$ sodium xanthine substrate and reacting the mixture at $37^{\circ} \mathrm{C}$, and calculating the activity according to the standard curve; the unit of the enzyme was displayed as the amount of uric acid in nmole produced by $1 \mathrm{~m} \ell$ of protein in one minute. Glutathione reductase (GRD) activity was measured by adding $0.94 \mathrm{mM}$ EDTA, $4.6 \mathrm{mM}$ oxidized glutathione, $0.16 \mathrm{mM} \mathrm{NADPH}$ and the enzyme solution in $0.1 \mathrm{M}$ potassium phosphate buffer ( $\mathrm{pH}$ 7.5) among the reaction mixture, then reacting the mixture at $37^{\circ} \mathrm{C}$ for 10 minutes, then measuring the absorbance of the reduced amount of NADPH at $34 \mathrm{~nm}$ and calculating it from the standard curve; the unit of enzyme activity was expressed as nmole of the amount of reduced glutathione produced by $1 \mathrm{mg}$ protein per minute; hepatic glutathione (GSH) content in the liver tissue was measured by adding $0.5 \mathrm{~m} \ell$ of $4 \%$ sulfosalicylic acid in $0.5 \mathrm{~m} \ell$ of liver tissue homogenate, then centrifuging the mixture at $2500 \mathrm{rpm}$ for $10 \mathrm{~min}$, then sampling $0.3 \mathrm{~m} \ell$ of the supernatant, then adding $2.7 \mathrm{ml}$ of disulfide reagent and leaving it for 20 minutes, then measuring absorbance at $412 \mathrm{~nm}$ and calculating in accordance with the standard curve [11].

\subsection{Data Processing and Analysis Method}

Statistical data analysis for this experiment was performed using the PASW statics windows (ver 18.0); the mean and standard deviation of the measured variables were calculated for each group. In addition, one-way ANOVA was conducted to verify the significance between each group, and Duncan's multiple range test was performed as a post-hoc comparison if proved significant between groups. The significance level a was .05.

\section{Results of Research}

\subsection{Analysis of hyperlipidemia-related blood components}

According to the result of hyperlipidemic blood components analysis, the plasma triglyceride level 
showed higher in high fat diet group than in normal diet group, demonstrating the induction of hypertriglyceridemia $(\mathrm{p}<.05)$, and was improved to the level of normal diet group by applying pulsed electromagnetic field $(\mathrm{p}<.05)$ [Table 1].

The total plasma cholesterol concentration showed higher in high fat diet group than in normal diet group, demonstrating the induction of hypercholesterolemia $(\mathrm{p}<.05)$, and the hypercholesterolemia was improved to the level of normal diet group by applying pulsed electromagnetic field $(\mathrm{p}<.05)$. The plasma glucose concentration showed higher in high fat diet group than in normal diet group $(\mathrm{p}<.05)$, and was improved to the level of normal diet group by applying pulsed electromagnetic field $(\mathrm{p}<.05)$. The plasma insulin concentration showed higher in high fat diet group than in normal diet group $(\mathrm{p}<.05)$, and was improved to the level of normal diet group by applying pulsed electromagnetic field $(\mathrm{p}<.05)$.

\subsection{Analysis of hyperlipidemia-related blood componentsAnalysis of antioxidant enzymes and reactive oxygen}

According to the result of antioxidant enzymes and reactive oxygen analysis, in the change of GSH and GRD related with the reaction of antioxidant enzymes, GSH showed lower value in high fat diet group than in normal diet group $(\mathrm{p}<.05)$, and was improved to the level of normal diet group by applying pulsed electromagnetic field $(\mathrm{p}<.05)$. In addition, GRD showed lower value in high fat diet group than in normal diet group $(\mathrm{p}<.05)$, and was improved to the level of normal diet group by applying pulsed electromagnetic field $(\mathrm{p}<.05)$ [Table 2].

In the change in $\mathrm{XO}$ and $\mathrm{MDA}$ related with the reaction of lipid peroxidation and reactive oxygen, $\mathrm{XO}$ showed higher value in high fat diet group than in normal diet group $(\mathrm{p}<.05)$, and was improved to the level of normal diet group by applying pulsed electromagnetic field $(\mathrm{p}<.05)$. In addition, MDA showed higher value in high fat diet group than in normal diet group $(\mathrm{p}<.05)$, and was improved to the level of normal diet group by applying pulsed electromagnetic field $(\mathrm{p}<.05)$.

\section{Discussion}

The present study was aimed to determine the impact of the pulsed electromagnetic field on the changes in blood components, antioxidant enzymes and reactive oxygen by applying a pulsed electromagnetic field to high-fat diet induced hyperlipidemic rats.

In the study associated with blood components, the high-fat diet group showed higher serum triglyceride and total cholesterol concentrations than the normal diet group, which verified that hyperlipidemia was

Table 1. Effects of pulsed electromagnetic field on blood components.

\begin{tabular}{|c|c|c|c|c|c|}
\hline Group & $\begin{array}{l}\text { Triglyceride } \\
(\mathrm{mg} / \mathrm{dl})\end{array}$ & $\begin{array}{c}\text { Total cholesterol } \\
(\mathrm{mg} / \mathrm{dl})\end{array}$ & $\begin{array}{c}\text { Free fatty acid } \\
(\mu \mathrm{Eq} / 1)\end{array}$ & $\begin{array}{l}\text { Glucose } \\
(\mathrm{mg} / \mathrm{dl})\end{array}$ & $\begin{array}{l}\text { Insulin } \\
(\mu \mathrm{U} / \mathrm{ml})\end{array}$ \\
\hline \multirow{2}{*}{ GD } & 45.35 & 69.38 & 651.91 & 91.11 & 26.98 \\
\hline & \pm 3.17 & \pm 3.13 & \pm 68.61 & \pm 6.76 & \pm 7.78 \\
\hline \multirow{2}{*}{$\mathrm{HD}$} & 65.31 & 103.49 & 731.68 & 141.41 & 41.31 \\
\hline & \pm 3.26 & \pm 6.88 & \pm 45.36 & \pm 13.46 & \pm 6.38 \\
\hline \multirow{2}{*}{$\mathrm{HDP}$} & 43.58 & 79.14 & 655.93 & 98.37 & 34.26 \\
\hline & \pm 2.81 & \pm 5.12 & \pm 68.33 & \pm 21.29 & \pm 5.99 \\
\hline $\mathrm{F}$ & $75.441 *$ & 98.831* & 3.012 & $40.176 *$ & $12.011 *$ \\
\hline Duncan & GD,HDP $<\mathrm{HD}$ & $\mathrm{GD}<\mathrm{HDP}<\mathrm{HD}$ & & $\mathrm{GD}, \mathrm{HDP}<\mathrm{HD}$ & $\mathrm{GD}<\mathrm{HDP}<\mathrm{HD}$ \\
\hline $\begin{array}{l}\text { The values } \\
\text { GD : Genes } \\
\text { HD : High } \\
\text { HDP : Hig }\end{array}$ & $\begin{array}{l}\text { ported as the } m \\
\text { group } \\
\text { t; group }\end{array}$ & $* \mathrm{p}<.05$ & & & \\
\hline
\end{tabular}


induced and is the similar result to the previous study of Kim [9] and Chen [12] that demonstrated the induction of hyperlipidemia by the long-term high-fat diet.

In addition, hypertriglyceridemia and hypercholesterolemia thus induced by long-term high-fat diet were improved to the level of the normal diet group by applying a pulsed electromagnetic field, which is the similar result to the study of Ko [11] who reported that regular exercise such as swimming was effective in improving hyperlipidemia, and which verified that the application pulsed electromagnetic field had positive effect on the improvement of blood components of the hyperlipidemic rats.

Further, hyperglycemia and hyperinsulinemia were also improved close to the normal diet group through the application of pulsed electromagnetic field, which is believed to be from the reduced insulin resistance in peripheral tissues, hyperactivity of glycogen synthase, and the increased expression of sugar transporter [13].

As seen from the outcomes of the study related to antioxidant enzymes, GSH and GRD showed lower levels in high-fat diet group than in normal diet group, but were improved to the level of normal diet group through the application of pulsed electromagnetic field, which is the similar result to the study of Netreva [14], who reported that regular physical exercise caused an increase in the antioxidant capacity and reduced the adverse reactions of reactive oxygen; this study also showed that antioxidant enzymes in the body of the high-fat diet-induced hyperlipidemic rats, but that pulsed electromagnetic field has significantly increased the reaction of antioxidant enzymes, thus reducing reactive oxygen.

The lipid peroxidation generated in the cell membrane by reactive oxygen nonspecifically attacks the cell membrane and cause accumulation of the aging pigment that ultimately leads to cell death, and there is a report that the amount of lipid peroxidation cab be recognized by the measure of $\mathrm{MDA}$ [15]. It was found in this study that the adverse effects caused by reactive oxygen was higher in hyperlipidemia induced rats compared with normal rats because the high-fat diet group showed high levels of MDA than the normal diet group. However, as the results of applying pulsed electromagnetic field, it was found that the high MDA levels in the high-fat diet group were improved to the level of the normal diet group, which means the application of pulsed electromagnetic field has a positive effect on the inhibition of adverse effects caused by reactive oxygen.

In the case of XO, Alessio and other authors [16-20] reported that oxidative stress is associated with the free radical activity and that the resistance to XO has increases in the subjects who had regular training by the exercise of medium strength; this report is similar

Table 2. Effects of pulsed electromagnetic field on GSH, GRD, XO and MDA

\begin{tabular}{|c|c|c|c|c|}
\hline \multirow[b]{2}{*}{ Group } & GSH & & $\mathrm{XO}$ & \multirow{2}{*}{$\begin{array}{c}\text { MDA } \\
(\mathrm{nmole} / \mathrm{ml})\end{array}$} \\
\hline & ( $\mu$ mole $/ \mathrm{g}$ tissue) & nmole/mg protein/min) & $\begin{array}{c}\text { (uric acid nmole/mg } \\
\text { protein } / \mathrm{min} \text { ) }\end{array}$ & \\
\hline \multirow{2}{*}{ GD } & 23.46 & 22.63 & 3.63 & 29.63 \\
\hline & \pm 3.38 & \pm 3.08 & \pm .31 & \pm 3.89 \\
\hline \multirow{2}{*}{$\mathrm{HD}$} & 13.82 & 12.9 & 4.04 & 46.78 \\
\hline & \pm 4.23 & \pm 3.32 & \pm .29 & \pm 5.68 \\
\hline \multirow{2}{*}{$\mathrm{HDP}$} & 24.12 & 22.89 & 3.53 & 31.72 \\
\hline & \pm 3.46 & \pm 3.21 & \pm .31 & \pm 3.92 \\
\hline $\mathrm{F}$ & 48.134* & $25.894 *$ & 11.991* & $29.902 *$ \\
\hline Duncan & $\mathrm{HD}<\mathrm{HDP}, \mathrm{GD}$ & $\mathrm{HD}<\mathrm{GD}, \mathrm{HDP}$ & $\mathrm{HDP}, \mathrm{GD}<\mathrm{HD}$ & $\mathrm{GD}, \mathrm{HDP}<\mathrm{HD}$ \\
\hline \multicolumn{5}{|c|}{$\begin{array}{l}\text { The values are reported as the mean } \pm \text { SD. } * \mathrm{p}<.05 \\
\text { GD : General Diet group } \\
\text { HD : High fat Diet; group }\end{array}$} \\
\hline
\end{tabular}


to the outcome of this study that demonstrated the reduction of $\mathrm{XO}$ in the high-fat diet inducedhyperlipidemic rats, by applying pulsed electromagnetic field for six weeks. In other words, the six-week's applied pulsed electromagnetic field was an effective exercise to the reduction of $\mathrm{XO}$ in hyperlipidemic rats induced by a high-fat diet.

\section{Conclusion}

High-fat diet has increased plasma triglycerides, total cholesterol, glucose and insulin concentration, but the applied pulsed electromagnetic field has improved the concentrations of triglyceride, total cholesterol, glucose and insulin; the results imply the positive effect of pulsed electromagnetic field on the improvement of blood components in plasma. In addition, high-fat diet has reduced GSH and GRD associated with antioxidant enzymes and increased $\mathrm{XO}$ and MDA associated with the reaction of reactive oxygen, compared to a normal diet; but the application of pulsed electromagnetic field has showed improvement effect by increasing GSH and GRD, that were decreased due to a high-fat diet, to the level of the normal diet group, and by reducing the increased MDA and XO to a level of normal diet group. Furthermore, these results implies the positive effects of pulsed electromagnetic field on the promotion of the activation of antioxidant enzymes and inhibition of the reaction of reactive oxygen.

Therefore, the applied pulsed electromagnetic field can be the effective treatment for changes in the blood composition of hyperlipidemic rats, enhancement of antioxidative activity and the inhibition of reactive oxygen.

\section{REFERENCES}

[1] J. Davis, M. Murphy, T. Trinick, E. Duly, A. Nevil,
G. Davison, Acute effects of walking on inflammatory and cardiovascular risk in sedentary post-menopausal women. J Sports Sci, vol. 26, no. 3, pp. 303-309, 2008.

[2] A. R. Pathan, A. B. Gaikwad, B. Viswanad, P. Ramarao, Rosiglitazone attenuates the cognitive deficits induced by high fat diet feeding in rats. Eur J Phamacol, vol. 589, no. 1-3, pp. 176-179, 2008.

[3] M. W. Hulver, J. A. Hournard, Plasma leptin and exercise: recent findings. Sports Med, vol. 33, no. 7, pp. 473-482, 2003.

[4] J. E. Turner, N. J. Hodges, J. A. Bosch, S. Aldred, Prolonged depletion of antioxidant capacity after ultraendurance exercise. Med Sci Sports Exerc, vol. 43, no. 9, pp. 1770-1776, 2011.

[5] D. H. Kwon, B. S. Kim, H. Chang, Y. I. Kim, S. A. Jo, Y. H. Leem, Exercise ameliorates cognition impairment due to restraint stress-induced oxidative insult and reduced BDNF level. Biochem Biophys Res Commun, vol. 434, no. 2, pp. 245-251. 2013.

[6] R. H. Funk, T. K. Monsees, Effects of electromagnetic fields on cells: physiological and therapeutical approaches and molecular mechanisms of interaction. A review. Cells Tissues Organs, vol. 182, no. 2, pp. 59-78, 2006.

[7] C. T. Rubin, K. J. McLeod, L. E. Lanyon, Prevention of osteoporosis by pulsed electromagnetic fields. J Bone Joint Surg Am, vol. 71, no. 3, pp. 411-417, 1989.

[8] B. F. Sisken, J. Walker, M. Orgel, Prospects on clinical applications of electrical stimulation for nerve regeneration. J Cell Biochem, vol. 51, no. 4, pp. 404-409, Review, 1993.

[9] C. H. Kim, J. H. Youn, J. Y. Park, S. K. Hong, K. S. Park, S. W. Park, K. I. Suh, K. U. Lee, Effects of high-fat diet and exercise training on intracellular glucose metabolism in rats. Am J Physiol Endocrinol Metab, vol. 278, no. 6, pp. 977-984, 2000.

[10] J. S. Gilbert, C. T. Banek, A. J. Bauer, A. Gingery, 
K. Needham, Exercise training attenuates placental ischemia-induced hypertension and angiogenic imbalance in the rat. Hypertension, vol. 60, no. 6, pp. 1545-1551, 2012.

[11] K. J. Ko, The Effect of Swimming Exercise by Load on Blood Components, Antioxidant Enzymes and Reactive Oxygen in Rats. Journal of Korean Society for the Study of Physical Education, vol. 7, no. 3, pp. 247-255, 2002.

[12] M. T. Chen, L. N. Kaufman, T. Spennetta, E. Shrago, Effects of high fat-feeding to rats on the interrelationship of body weight, plasma insulin, and fatty acyl-coenzyme A, esters in liver and skeletal muscle. Metabolism, vol. 41, no. 5, pp. 564-569, 1992.

[13] G. Zhang, N. Shirai, H. Suzuki, Relationship between the effects of dietary fat on swimming endurance and energy metabolism in aged mice. Ann Nutr Metab, vol. 58, no. 4, pp. 282-289, 2011.

[14] A. Netreba, D. Popov, Y. Bravyy, E. Lyubaeva, M. Terada, T. Ohira, H. Okabe, O. Vinogradova, Y. Ohira, Responses of knee extensor muscles to leg press training of various types in human. Ross Fiziol Im I M Sechenova, vol. 99, no. 3, pp. 406-416, 2013.

[15] T. Zima, V. Tesar, S. Stipek, J. Crkovská, R. Poledne, J. Tĕminová, J. Plátenik, I. Rychlik, M. Merta, K. Němecek, The influence of cyclosporin on lipid peroxidation and superoxide dismutase in adriamycin nephropathy in rats. Nephron, vol. 75, no. 4, pp. 464-468, 1997.

[16] H. M. Alessio, Exercise induced oxidative stress. Med Sci Sports Exerc, vol. 25, no. 2, pp. 218-224, 1993.

[17] E. Jówko, J. Sacharuk, B. Balasinska, J. Wilczak, M. Charmas, P. Ostaszewski, R. Charmas, Effects of a single dose of green tea polyphenols on the blood markers of exercise-induced oxidative stress in soccer players. Int J Sport Nutr Exerc Metab, vol. 22, no. 6, pp. 486-496, 2012.

[18] H. Gatterer, J. Greilberger, M. Philippe, M.
Faulhaber, R. Djukic, M. Burtscher, Short-term supplementation with alpha-kwtoglutaric acid and 5-hydroxymethylfurfural does not prevent the hypoxia induced decrease of exercise performance despite attenuation of oxidative stress. Int J Sports Med, vol. 34, no. 1, pp. 1-7, 2013.

[19] P. C. Silveira, Da SilvaLA, P. T. Tromm, L. Dda. Scheffer, C. T. de Souza, R. A. Pinho, Effects of therapeutic pulsed ultrasound and dimethylsulfoxide phonophoresis on oxidative stress parameters after injury induced by eccentric exercise. Ultrasonics, vol. 52, no. 5, pp. 650-654, 2012.

[20] R. A. Olek, K. Safranow, K. Jakubowska, M. Olszewska, D. Chlubek, R. Laskowski, Allopurinol intake does not modify the slow component of $\mathrm{V}(.) \mathrm{O}(2)$ kinetics and oxidative stress induced by severe intensity exercise. Physiol Res, vol. 61, no. 1, pp. 89-96, 2012.

\section{방 현 수(Bang, Hyun Soo)}

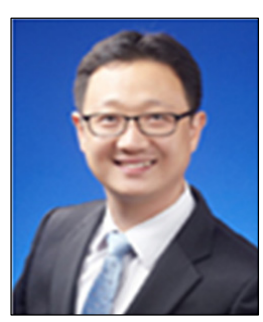

·2006년 2월 : 대구대학교 물리치료 학과(이학사)

· 2008년 2월 : 대구대학교 재활과학 과(이학석사)

- 2011년 2월 : 대구대학교 재활과학 과(이학박사)

- 2009년 3월 현재 : 김천대학교 물리치료학과 교수

- 관심분야 : 해부생리학, 조직학, 약리학

·E-Mail : 76044860@hanmail.net

\section{정 인 호(Jeong, In Ho)}

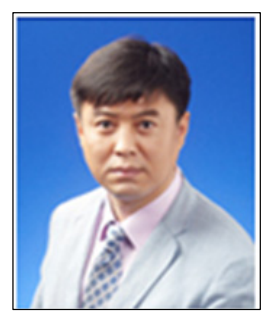

- 1999년 2월 : 경산대학교 보건과학 과(보건학사)

- 2003년 2월 : 경산대학교 보건학석 과(보건학석사)

- 2008년 2월 : 대구한의대학교 보건 학과(보건학박사)

· 2005년 3월 현재 : 김천대학교 치기공학과 교수

- 관심분야 : 치과재료학, 치과도재기동학

·E-Mail : jih4611@gimcheon.ac.kr 
이 상 덕(Lee, Sang Deok)

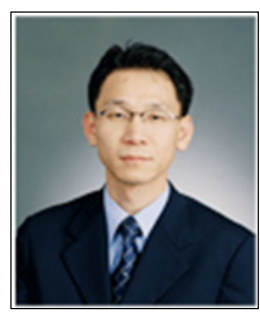

· 1997년 2월 : 성균관대학교 물리학 과(이학사)

· 2002년 2월 : 성균관대학교 물리학 과(이학석사)

· 2005년 2월 : 성균관대학교 물리학 과(이학박사 수료)

·2005년 3월 현재 : 김천대학교 안경광학과 교수

· 관심분야 : 시과학, 안과학

·E-Mail : elesd@hanmail.net 